\title{
Race, populations, and genomics: Africa as laboratory
}

\author{
Lundy Braun ${ }^{\mathrm{a}, \mathrm{b}, *}$, Evelynn Hammonds ${ }^{\mathrm{c}}$ \\ a Department of Pathology and Laboratory Medicine, Brown University, Box G, Providence, RI 02910, United States \\ ${ }^{\mathrm{b}}$ Department of Africana Studies, Brown University, Box G, Providence, RI 02910, United States \\ ${ }^{\mathrm{c}}$ History of Science and African and African American Studies, Harvard University, Cambridge, MA, United States
}

\section{A R T I C L E I N F O}

\section{Article history:}

Available online 26 August 2008

\section{Keywords:}

Africa

Race

Population

Genetics

Social anthropology

Linguistics

\begin{abstract}
A B S T R A C T
Much of the recent debate over race, genetics, and health has focused on the extent to which typological notions of race have biological meaning. Less attention, however, has been paid to the assumptions about the nature of "populations" that both inform contemporary biological and medical research and that underlie the concept of race. Focusing specifically on Africa in the 1930s and 1940s, this paper explores the history of how fluid societies were transformed into bounded units amenable to scientific analysis. In the so-called "Golden Age of Ethnography," university-trained social anthropologists, primarily from Britain and South Africa, took to the field to systematically study, organize, and order the world's diverse peoples. Intent on creating a scientific methodology of neutral observation, they replaced amateur travelers, traders, colonial administrators, and missionaries as authoritative knowledge producers about the customs, beliefs, and languages of indigenous peoples. At the same time, linguists were engaged in unifying African languages and mapping language onto primordial "tribal" territories. We argue that the notion of populations or "tribes" as discrete units suitable for scientific sampling and classification emerged in the 1930s and 1940s with the ethnographic turn in social anthropology and the professionalization and institutionalization of linguistics in Western and South African universities. Once named and entered into international atlases and databases by anthropologists in the U.S., the existence of populations as bounded entities became self-evident, thus setting the stage for their use in large-scale population genetic studies and the contemporary reinvigoration of broad claims of difference based on population identification.
\end{abstract}

(c) 2008 Elsevier Ltd. All rights reserved.

\section{Introduction}

After a one-day public hearing in June 2005, the U.S. Food and Drug Administration (FDA) approved Nitromed Inc.'s patent application for BiDil, a drug purportedly more effective in treating heart failure among African Americans (Kahn, 2007). While the approval and promotion of BiDil specifically to African Americans has generated much controversy over the meaning of race, the scientific quest for the genetic roots of racial difference and genetic

\footnotetext{
* Corresponding author. Tel.: +1 4018633308.

E-mail addresses: lundy_braun@brown.edu (L. Braun), evelynn_ hammonds@harvard.edu (E. Hammonds).
}

explanations of health disparities continues unabated (Mountain \& Risch, 2004). Why are genetic understandings of race so resilient? And, what are the global implications of this initially U.S.-centered, but increasingly international, debate?

While typological notions of race have been largely discredited, one dimension of race that has not been fully explored is the relationship between race and what Lisa Gannett (2001) refers to as "population thinking," which foregrounds the study of territorially defined units, variably described as "populations," "tribes," or "ethnic groups." We suggest that the insufficiently examined concept of "population," which emerged in Europe linked to nation-state formation at the end of the eighteenth century (Foucault, 1976) 
but became centered in Africa on smaller geographically delineated units, underlies and is conflated with the notion of race deployed in various settings, be it forensic analysis, population genetics, biomedical research, ancestry testing, or health disparities research. In this paper, we explore how research in the human sciences that established populations as closed systems, suitable for empirical investigation, intersected with biological investigations of human difference, especially in the fields of population genetics and biomedicine. As the locus of debates over the origins of humans, a repository of cultural stereotypes of famine, disease, and violence, and an anthropological laboratory, Africa has occupied a position of particular importance in the scientific imagination. For many scientists, sub-Saharan Africa is critical to the understanding of human migration patterns, genetics of complex disease, and racial disparities in disease (Cavalli-Sforza \& Feldman, 2003; Kittles \& Weiss, 2003; Tishkoff \& Williams, 2002).

Focusing on Africa in the late nineteenth and the first half of the twentieth century, we examine the specific role of two expert knowledge systems - linguistics and social anthropology - to track the production of the concept of "population," "tribes," or "ethnic groups" as bounded units amenable to scientific sampling, analysis, and classification, and central to contemporary notions of race. We propose that boundedness hardened from the early twentieth century to the 1960s, as the linguistic and ethnographic preoccupations of travelers, missionaries, and colonial administrators became professionalized and institutionalized in British, African, and U.S. universities. Once named and entered into international atlases and databases by anthropologists in the U.S., the existence of populations as distinct, naturally occurring, static formations became selfevident, thus setting the stage for their use in large-scale population genetic studies - and for the reinvigoration of broad claims of human difference based on population identity. Our purpose is not to deny the rich diversity of the human species. Rather, the goal of this essay is to elucidate the historical assumptions embedded in the unit of analysis.

\section{The Human Genome Diversity Project and the HapMap}

To be useful in comparative genetic investigations, populations must be isolated - geographically, linguistically, socially, and/or culturally - in a relatively unchanged state over a long period of time, thereby constituting "gene pools." The requirement for isolation was evident in the 1991 call by leading population geneticists to organize the Human Genome Diversity Project (HGDP), so insightfully analyzed by Amade M'Charek (2005) and Jenny Reardon (2005). Organizers of the HGDP pointed to an immediate and vanishing opportunity to sample the world's population diversity systematically, using the latest molecular biological technologies. "The populations that can tell us the most about our evolutionary past," the authors write, "are those that have been isolated for some time, are likely to be linguistically and culturally distinct, and are often surrounded by geographic barriers...Such isolated human populations are being rapidly merged with their neighbors...destroying irrevocably the information needed to reconstruct our evolutionary history" (Cavalli-Sforza,
Wilson, Cantor, Cook-Deegan, \& King, 1991, p. 490). For organizers of the HGDP, the existence of "populations" was given. It was simply a technical question of rapidly assembling the requisite linguistic expertise to trace the coevolution of genes and languages and anthropological expertise to prioritize the units for sampling and to describe population characteristics relevant to genetic research.

The idea that genes and language co-evolved builds on linguistic theories that language groupings are fixed and bounded entities with a shared genetic ancestry, such that language can be mapped with reasonable scientific certainty onto anthropologists' tribes (Cavalli-Sforza \& Feldman, 2003). In lending the authority of science to what had previously been unsystematic, but culturally powerful, musings about human nature, groups and difference, anthropological, linguistic and natural scientific theorizing and practices played a vital role in producing African groups as distinct and fixed entities. Ethnicity was revitalized for complex reasons in post-independence African nations, making it difficult for us in the early twenty-first century to view "tribes" or "ethnic groups" as socially produced and therefore continually changing formations.

In 2002, Rosenberg et al. published the first report using a panel of cell lines assembled by the HGDP and the Centre d'Etude of Polymorphisms Humaine (CEPH) (Cann et al., 2002). On the basis of genotyping a mere 1056 individuals from 52 "pre-defined" populations, the investigators claimed to have uncovered the underlying "genetic structure of human populations." In a telling footnote, the authors note that differences between groups might be exaggerated if "isolated and geographically well-separated populations [are used] to construct samples" (Rosenberg et al., 2002, p. 2384) but argue that their sample did not contain such a methodological flaw. A map of sampled populations in the supplementary materials, however, reveals widely separated, continentally determined groups, all with small sample sizes. Only six "populations" represent the entire continent of Africa. Importantly, assumptions related to population sampling are built into the computer program structure used by population geneticists, assigning individuals to populations, with the number of populations $(K)$ determined in advance by the user, thus shaping interpretation of the data (Duster, 2006). There is no evidence that the strong correlation between continent of origin and the six genetic clusters $(K=6)$ reported by Rosenberg et al. represented the most likely clustering in their database (Bolnick, 2008).

What is pertinent to this discussion is that these authors employed the language of "population," not race, and left unstated how populations were defined in the initial sampling protocol. The online supplementary materials to a letter in Science announcing the availability of the cell lines (Cann et al., 2002) do provide a map, a list of each population, its geographic coordinates, sample size, and gender of sample but without a working definition of population, who collected the samples, or when sampling was conducted. Thus this very critical first step in the design of such a seminal scientific study remains a black box.

That continental clusters, however, were thinly disguised surrogates for race was made clear when 
Nicholas Wade (2002) of the New York Times claimed that the study proved the existence of races. Citing interviews with study authors, Wade asserted that "these regions broadly correspond with popular notions of race." Subsequently, numerous commentators have repeatedly invoked these results as evidence for the "existence" of continentally defined racial groups (Burchard et al., 2003; Mountain \& Risch, 2004), while other scholars have subjected the results to incisive critiques (Duster, 2005, 2006).

Analogous problems related to the unit of study plague the HapMap project, a similar but distinct international collaboration of over 200 scientists whose goal is to map common patterns of human DNA sequence variation and to identify genetic variants that characterize complex diseases. Rather than undertaking the more laborious and expensive sequencing of individual genomes in their entirety, the HapMap project employs the ingenious technique of analyzing mutations in shorter blocks of DNA called haplotypes (International HapMap Consortium, 2003). Although comparison of genetic difference by race, ethnicity, or geographic location was not the primary goal of the HapMap project, the Consortium nonetheless chose to categorize their sample collection according to continental ancestry. In its first publication, the Consortium explicitly stated "no populations are typical, special or sharply bounded" (p. 791). Nonetheless, at least loosely defined notions of boundedness informed the selection of populations. The Yoruba became the representative population of Africa, Japanese and Han Chinese of Asia, and a U.S. population from the state of Utah of Northern and Western Europe. Interestingly, criteria for assignment of membership in a population varied by socio-cultural group - "for the Yoruba, by asking the donor whether all four grandparents were Yoruba, for the Han Chinese by asking the donor whether at least three of four grandparents were Han Chinese, and for the Japanese by self-identification" (p. 791). The method by which Northern or Western European ancestry was assessed was left unstated. Despite the caution of organizers, early scientific and popular press reports from this database affirmed genetic difference between what they referred to as "ethnic groups." (McPherson et al., 2007; Wade, 2005).

\section{Language, missionaries and the invention of tribes in Africa}

These loose or nonexistent definitions of populations in the scientific literature suggest that the idea of humans as naturally organized into discrete populations, tribes, or ethnic groups is deeply embedded in Western thought. However, as historian Leroy Vail (1989) has shown, ethnicity is not a simple reflection of a "traditional" or tribal past insulated from historical change. Rather, in Africa concepts of ethnicity were formed and re-formed during the late nineteenth and twentieth centuries in response to the social, political, and economic dynamics of African societies, the rapid changes triggered by colonialism and industrialization, and intellectual work in linguistics and anthropology.

Prior to the twentieth century, in accounts that resonate with rich, if offensive, ethnographic detail, travelers,
European missionaries, and colonial administrators embraced the project of producing knowledge about Africans, publicized their work in the metropole in museum exhibits, books, pamphlets, and the popular press, and used their understandings to guide colonial policy and resolve metropolitan social anxieties (Coombes, 1995; Kuklick, 1991; Moore, 1993; Mudimbe, 1988). Working with African intellectuals, Europeans conducted anthropological, ethnological, and linguistic studies, writing the history of tribes, constructing written African languages, and describing the details of rites, customs, and religious practices of indigenous peoples.

Initially reliant on interpreters, whom they did not trust to accurately convey their message, missionaries placed high priority on learning African languages and reducing them to a written form (Moffat, 1844, p. 200). Soon after settling among the Tswana in the 1820s, Robert Moffat of the London Missionary Society, for example, created a spelling book in Tswana and began translating the Bible and other religious texts. In 1857, he published, printed, and distributed the first translation of the Bible. The process of constructing a written language from an oral one, however, was not a mere reflection of what Africans spoke but in the case of Moffat involved turning one variant in the Tswana language continuum into a written language, which served to create the Tswana as a distinct group of people.

By the end of the nineteenth century, codification of language was a more sophisticated enterprise. To further their evangelical work and unify their converts, Swiss missionaries worked with African assistants in the late nineteenth century to devise from the diverse languages of the coastal peoples from south-east Africa, all of which had been influenced by Zulu, Gaza, and Swazi, a single written language and to teach this language in mission schools (Harries, 1989). Operating within the conventions of print culture, they created grammar, vocabulary, Bibles, and literature.

Initially interested in entymology in his first tour in Africa, Swiss missionary and anthropologist Henri Junod quickly found that "Man is infinitely more interesting than the insect" (Harries, 1981; Junod, 1927, p. 1). Mastering the language of local speakers around the mission station at Lorenzo Marques, he published a grammar of the Ronga dialect in 1896 and the Djonga dialect in 1908 (Junod, 1927, p. 29; Michler, 2003, pp. 46-58). Consciously scientific in its methods and goals, his ethnography The life of a South African tribe, complete with a color-coded map, was important in labeling the "Thonga," a geographically dispersed group of people speaking a range of dialects, as a single tribe, even though there was "no true national unity amongst the Thongas" and they were "hardly conscious that they form a definite nation" (pp. 14-15). Acknowledging that "the word Ba-Thonga does not enjoy much more favor and is not quite satisfactory," he nonetheless thought "it ought to be accepted in the course of time without much difficulty" (p. 16). For Junod, language together with physical and mental characteristics defined the tribe.

But, as Patrick Harries (1989) points out (and as Junod was aware), the term "Tsonga-speaking" in the nineteenth century suggests linguistic coherence that did not exist. The 
word Tonga was first used pejoratively by Africans and later by colonists to describe heterogeneous groups of migrants speaking different language forms and holding different cultural affinities who fled to the northern and eastern Transvaal from southern Mozambique in the nineteenth century to escape domination by the Zulu kingdom, civil war in Mozambique, and ecological crises. Southern Mozambiquan peoples, variously referred to as Gwambas, Koapas, Tongas, Toka, Knowbnoses, Tchekes, Bonos, Shangaans, were linked not by language but by their skills as traders, their diet and methods of food preparation, their social organization and, importantly, their social exclusion as foreigners in the Transvaal. Their patterns of settlement were geographically dispersed with no unifying political organization and, not surprisingly, they intermingled with resident peoples. With their continued social exclusion and alienation from the land, a sharp division of labor and housing in the gold mines structured along tribal lines, a Native Affairs Department that encouraged tribalism, and a mission-educated petty bourgeoisie schooled in written Tsonga, by the mid-twentieth century an ethnic consciousness, which was consolidated by the Bantustan system of the apartheid government, did indeed develop among Tsonga-speakers (Harries, 1989).

In the 1890s in eastern Zimbabwe, the people who gathered under Chief Makoni did not understand themselves as Manyika (Ranger, 1989). By 1930, a term that in the pre-colonial period referred to a narrowly circumscribed political allegiance and later was re-defined as the Portuguese and British who competed for territory, came to describe a cultural identity rooted in the primordial past of a people composed of residents and settlers in a large geographic area. This shift in identity over the course of four decades required the standardization of a single written Manyika language, with an orthography and grammar, out of a range of dialects, which was undertaken by missionaries of the American Methodist Episcopal Church, the Anglicans, and the Trappist/Mariannhill Catholics. Working in close association with African converts, they wrote and translated religious works, folktales, and literature. Each worked among people who differed in their means of subsistence, interest in linguistics and literacy, and receptivity to missionary work. In constructing a single written language form, "differences were exaggerated" and gradualism of "dialect zones" was erased (Ranger, 1989, p. 127). Despite competing interests, a Manyika identity was consolidated in the 1930s under the pressure of the migrant labor system as residents in eastern Zimbabwe married "foreign women" and mission-influenced labor migrants drew on this identity to survive the dislocation of migrancy (Ranger, 1989, p. 140).

While promoting tribalism was certainly not an explicit objective of missionary linguistic work, missionaries were nonetheless working within a European system of knowledge that produced what Harries calls "a pattern of domination" (Harries, 1987). Indeed, language was and is a powerful constructor of communal memory (Makoni, 1998). The leap from linguistic group to tribes with defined characteristics and fixed boundaries was but a short one in ordering the universe. The pertinent point for this discussion is that the pattern of domination that naturalized population groups as stable units of study erased a complex history of intermingling of heterogeneous peoples in precolonial and colonial Africa - or, in the language of population genetics, continued and constant gene flow.

Despite the persistent efforts of the missionaries, standardization of African languages was only beginning in the late nineteenth and early twentieth centuries. Fixing tribal boundaries through language required institutional support and a coherent research agenda, which came after the First World War as language studies became institutionalized in South African universities. The School of African Life and Languages was founded at the University of Cape Town in 1921, followed by the establishment of the journal Bantu Studies in 1922 (Gordon, 1990). Funding of the International Institute of African Languages and Cultures (IIALC) in Britain, later the International African Institute, by the Rockefeller Foundation and the Carnegie Corporation provided stable support and encouragement for African studies (Kuklick, 1991). Its journal Africa became a major vehicle for the work of linguists and anthropologists. One of the first tasks of the IIALC was to devise principles for a uniform system of orthography (Hailey, 1938, p. 79).

Professional linguistics as a scientific discipline emerged in South Africa in the first decades of the twentieth century as segregation was hardening. Figures such as C. M. Doke and Gerald Paul Lestrade were prolific in their study of the languages of native people, serving on numerous government committees and journal editorial boards. Like Junod, language was a defining characteristic of the tribes they were studying (Lestrade, c. 1930). The principal concern of linguists at this time was to establish scientific principles to unify and standardize the diverse languages of Africa. Various government boards deliberated on the connections between orthography and related classificatory projects on race, language group and tribe (Report, 1926). With the establishment of a sub-committee on language set up by the Inter-University Committee for African Studies in 1932, the study of African languages in South Africa, understandings of "tribes" and their relationship to the South African government, became even more technically and scientifically based (Doke, 1933). But, reality defied the experts' classificatory schemes and pragmatic decisions had to be made. In his now classic survey of Africa, published in 1938, former colonial administrator in India Lord Hailey dismissed physical characteristics as scientifically useful in classifying African peoples. This left "language and cultural traits...as a basis for ethnic classification" (Hailey, 1938 , p. 18). For Hailey, the main issue was how knowledge of trained professionals could help colonial officials maintain traditional forms of social organization and mitigate the disruptive influence of Western civilization (Hailey, 1938, p. 1637).

\section{“Population thinking" and the emergence of social anthropology in Africa}

The increasingly technical debates amongst experts and the exigencies of British policies of indirect rule would ensure Africa's strategic role as a laboratory for the production of imperial knowledges in the twentieth and 
twenty-first centuries. Of particular significance to this discussion is that professionalization of linguistics was taking place at approximately the same time as anthropologists took to the field in Africa in large numbers, overlapping professionally but using different methods to define and investigate the unit of study. The typological thinking of physical anthropology with its emphasis on the study of racial origins dominated scientific discourse in South Africa for the first three decades of the twentieth century (Dubow, 1995). Beginning in the 1920s and continuing into the 1960s, however, social anthropologists of the functionalist school influenced both by Bronislaw Malinowski and A. R. Radcliffe-Brown ${ }^{1}$ turned to more systematic study of African societies. The ahistorical functionalist approach to anthropology required that social systems be bounded, static formations. Consequently, early studies were limited to "traditional," rural societies.

Scholars have critiqued the complicated political history of Malinowski's functionalism and Radcliffe-Brown's structuralism-functionalism, their relationship to the colonialist enterprise, and their internal dissensions (Asad, 1973; Cohn, 2004; Gluckman, 1940; Goody, 1995; Gordon, 1990; Hammond-Tooke, 1997; Kuklick, 1991; Kuper, 1996; Magubane, 1971; Mudimbe, 1988; Stocking, 1984). Our purpose here is not to rehearse these debates but to focus attention on the unit of study deployed by social anthropologists and how ethnographers both drew on pre-existing notions of populations and further hardened such ideas through their field studies and theoretical frameworks. "The question of the 'unit of study', far from being a methodological nicety, is a consequential theoretical matter" writes John Comaroff. "For fields of inquiry are never naturally given; they always reflect substantive assumptions about the constitution of the 'real' world" (Comaroff, 1982 , p. 144). Importantly, the unit of study helps to construct the 'real' world in ways that researchers themselves may not anticipate or intend.

While the intellectual core of functionalism and structural-functionalism is often located in Britain, it was social anthropologists in southern Africa, such as Godfrey and Monica Wilson, Isaac Schapera, Meyer Fortes, Max Gluckman, Winifred Hoernle, Richard and Eileen Krige, and Hilda Kuper who, with funding from organizations in Britain and the U.S., conducted extensive fieldwork in Africa. They went on to direct institutes in Africa, training many of the ethnographers who would ultimately hold prime academic positions back in the metropole (Goody, 1995; Kuper, 1996; Schumaker, 2001).

Neglecting culture, at least initially - and, of course, not totally - functionalists conceptualized human societies as closed social systems, in which each element had a functional relationship to the whole. They drew on Auguste

\footnotetext{
1 Briefly, functionalism refers to a theory of society developed most extensively by Bronislaw Malinowski and his followers. Functionalism takes an ahistorical view of society, holding that, like organisms, cultural phenomena and institutions of societies form an interconnected whole to fulfill the bio-psychological needs of the individual. Its variant, structural-functionalism, whose early proponent Alfred Reginald Radcliffe-Brown was heavily influenced by Emile Durkheim, focuses on how the component parts of society work together to maintain stable social systems.
}

Comte, Herbert Spencer, and especially Emile Durkheim for their theories of society and on the methods and practices of the natural sciences to provide purportedly objective accounts about the organization of human societies from which they could deduce key principles (Malinowski, 1935). For social anthropologists, boundedness was conferred by a synchronic framework in which social systems were held together by ties of kinship and/or political, legal, and religious institutions created to fulfill needs, be they bio-psychological in the case of Malinowski or social in the case of Radcliffe-Brown (Harris, 1968; Malinowski, 1930; Radcliffe-Brown, 1946). In other words, to take a functionalist approach, in which each of the parts relate to a whole, the unit of study had to be de-limited. The detailed diagrams, figures, tables, and detailed and systematic field notes of students of Malinowski gave material form to their self-consciously scientific orientation (Goody, 1995). Thus, published ethnographies, and the visual imagery they deployed, cast societies as static, resistant to change and, to varying extents, the people inhabiting this social structure without history, even though researchers found fitting people's customs into a functional framework a difficult task. In wrestling with the significance of African customs and social relationships, Radcliffe-Brown, for example, wrote somewhat tentatively "there is at present very good empirical evidence connecting father-right with the cattle complex and motherright with agriculture. But I do not think we can yet show any real functional correlation...The kinship systems will give us the first step in our analysis... after that we might go on to ancestor cults" (Radcliffe-Brown, 1925).

South African-born Meyer Fortes, a leading figure in British social anthropology for many decades, was unambiguous in his articulation of groups as self-contained. "A group of people bound together within a single social structure have a boundary, though not necessarily one that coincides with a physical boundary or is impenetrable." (Fortes, 1953, p. 22; quoted in Cohn, 2004, p. 202). Structures were, according to Fortes, "resistant to change" (Fortes, 1953, p. 23). For Radcliffe-Brown, culture was not bounded but "the system of society was contained within a territorially bounded community." (Stocking, 1984, p. 172). Like organic life, social systems had a functional unity (Radcliffe-Brown, 1935).

It is important to emphasize that social anthropologists were not an intellectually homogeneous group slavishly beholden to narrow theories of functionalism. Over time ethnographers developed theories of social change and did place social systems into broader contexts (Gluckman, 1940; Godfrey \& Wilson, 1945; Malinowski, 1929; Schapera, 1970) and wrote histories of South Africa (Wilson \& Thompson, 1969-1971). Nor were they insensitive to the Africans they were studying. Indeed, social anthropologists were a varied group from across the political spectrum, who struggled, often with great personal compassion, though of a decidedly paternalistic sort, to understand their research subjects and to rigorously test their hypotheses empirically in the field. Monica Wilson, for example, was a strong opponent of segregation and apartheid in South Africa (Anonymous, 1973). The lived realities of fieldwork made them acutely aware of the shortcomings of the 
theories of Malinowski and Radcliffe-Brown (Harris, 1968; Schumaker, 2001). In correspondence with Winifred Hoernle, Wilson remarked that the reality of fieldwork deviated from her theoretical training (Wilson, 1935). Noting that linguistically related peoples merge with each other, Elizabeth Colson acknowledges that "in a sense it is probably false to regard the Tonga as a definite group or a real unit which is set off by definite criteria from other peoples." Nor was the name "a common rallying point" for the people themselves (Colson, 1951, pp. 95-96). Nonetheless, she goes on to provide a detailed ethnographic description of this "tribe."

Thus, in focusing on the ethnographic present, functionalists were trapped, albeit uncomfortably, in a static worldview of African societies, effectively ignoring the history of movement and mingling of the people they studied. By concentrating on descent as the organizing principle of African societies, social systems were theoretically conceptualized as closed structures or, in the words of Radcliffe-Brown, as systems of "ordered social relations in a given collection of human beings" (Radcliffe-Brown, 1946). Movements of peoples in pre-colonial Africa (which for population geneticists would lead to gene flow between populations) are minimized conceptually. Change, when it occurred in 'simple' societies was considered to be slower than that occurring in 'complex' societies, a consequence of exogenous forces, such as colonialism, that reinforced the notion of a static, pre-colonial past. This point is clear in Godfrey and Monica Wilson's The analysis of social change based on observations in Central Africa (1945) which views "traditional" societies as only recently undergoing significant social change due to Western intervention.

Although anthropologists such as Evans-Pritchard developed nuanced understandings of the Nuer and conceived of his work as countering the prevailing views of colonial authorities (Evans-Pritchard, 1950; Goody, 1995), Bernard Cohn rightfully counters that conceptualizing African societies as organized into unchanging, bounded entities according to principles of descent was a legitimizing practice, enacted by social anthropologists, essential to maintenance of the social order under colonialism. "Unit, boundary, social structure, and group," Cohn writes, "are the central concepts which appear time and time again in the anthropological literature of the 1940s and the 1950s. A unit meant something that was observable on the ground. Hamlets, villages, lineages, tribes were believed to be bounded - they were countable and mappable, had names, and above all had social structures - patterned relations between groups. Groups were made up of individuals recruited on known principles, usually genealogical connections which were thought to be 'real,' i.e., met western concepts of descent traceable to common ancestors and expressed in the metaphor of 'blood"' (Cohn, 2004, p. 203).

A sense of urgency characterized the fieldwork of social anthropologists of the 1930s and 1940s for they were fully aware that the spread of industrialization and colonial interventions were changing indigenous societies rapidly and irrevocably. They branched out from studies of rural communities to urban settings and adapted their theoretical frameworks to the new conditions (Schumaker, 2001).
Radcliffe-Brown was so concerned with the rapid disappearance of "untouched" societies that he urged the Rockefeller Foundation to support a center for vanishing cultures at Yale (Stocking, 1984, p. 168). By the late 1960s, structural-functionalism was in decline. But, social anthropologists' social systems, defined on "scientific" principles, survived. Anthropologists' “tribes” could seamlessly double as geneticists "populations."

\section{The systematizing project of George Peters Murdock}

While social anthropologists began to critique the unit of study in the 1960s, the assumption of populations as discrete, bounded entities nonetheless hardened under the systematizing project of the American comparativist George Peter Murdock, who spent most of his career at Yale. Despite the many critiques of the theoretical framework and substance of his work (Harris, 1968), Murdock was highly influential in the history of anthropology. He served as president of numerous anthropological associations, was elected to the National Academy of Science in 1964, and trained many students, a large number of whom went on to hold prestigious positions at U.S. universities (Ferraro, 1992; Goodenough, 1994). Murdock's projects are of particular relevance to this discussion as his work helped to shape the conceptualization of population that informs contemporary population genetics research, such as the HGDP.

Influenced by physicians and evolutionist anthropologist W. H. R. Rivers, Murdock had limited fieldwork experience himself. From early in his career, he focused his efforts on ordering the ethnographic knowledge of others. Interested in cultural universals and statistical methodologies and animated by the desire to place the study of society on a scientific basis, Murdock first published a summary of ethnographies in 1934. Later in the 1930s with a team of assistants at Yale's Institute for Human Relations, he took on the mammoth task of creating the Cross-Cultural Survey, an archive of ethnographies later known as the Human Relations Area Files (HRAF).

Such a systematic effort, which incorporated ethnographies that were highly variable in quality and theoretical underpinnings (Harris, 1968, p. 615) and were conducted by fieldworkers operating in a variety of sometimes oppositional anthropological traditions, including those as distinct as Franz Boas and Malinowski, nonetheless facilitated statistical comparison of cultural traits by researchers the world over. According to Ward Goodenough, Murdock "seemed compelled to bring tidiness to things so that problems could be clarified" (Goodenough, 1994, p. 307). Through the mechanism of constructing scientific databases, the complexity of the history of societies and the ethnographers' interpretations of their research, as well as the distinctions between physical, social, and cultural characteristics of designated "tribes," were almost completely erased.

In 1957, Murdock published the "World Ethnographic Sample" (Murdock, 1957), followed by Outline of world cultures in 1958 (Murdock, 1958), a compilation of groups worldwide, distinguished by a simple coding system. Several years later, he began to compile a more comprehensive coded atlas of the world's peoples in Ethnology, 
a journal he founded in 1962, where he expanded on the number of societies available for cross-cultural analysis. The completed Ethnographic atlas, which contained a summary of 239 African societies organized into 85 clusters, was published as a single volume in 1967 (Murdock, 1967). By codifying social, cultural, and economic characteristics, such as mode of marriage, family organization, community organization, kin groups, settlement patterns and so on into a simplified form suitable for entry on punch cards and later into computer programs, Murdock promoted statistical comparisons of various traits of world societies. At the same time, he reduced dynamic societies to static forms and erased the nuanced understandings of social formations held by ethnographers. Indigenous peoples' own understandings of their history and their societies, not surprisingly, had no place in this academic endeavor. Identifying which cultures were essentially independent and ordering them into clusters was an organizational task reserved for anthropologists (Murdock, 1967, p. 3). Lost in this ambitious endeavor was the essential problem of the unit of study. As Marvin Harris (1968) writes: "The Files and all similar ethnographic samples are plagued by difficulties in establishing the boundaries of discrete socio-cultural systems..." (p. 615).

Although his own area of expertise was in North America and Oceania, Murdock had a special interest in Africa. In the mid-1950s he organized a graduate seminar at Yale on Africa. The outcome of these seminars was a book entitled Africa: Its peoples and their culture history published in 1959, a book of particular importance to Cavalli-Sforza. Framed as a reference guide, Africa is a highly readable text with a detailed index of African tribes based on the abundant ethnographic work accumulated on Africa in previous decades. In the preface to the book, Murdock makes special mention of the ethnographies of Evans-Pritchard, Fortes, Schapera, and Monica Wilson and draws on the accounts of social anthropologists, linguists, and travelers throughout his text. The definition of groups is unproblematic. "Tribes," he writes, "are classified into groups of essentially identical language and culture, arranged numerically in alphabetical order, with reasonably complete synonymies to facilitate identification through an index of tribal names included at the end of the book" (Murdock, 1959, p. ix). For Murdock, language was particularly informative of ancestral relationship. Recognizing that classical racial typologies were dated, he nonetheless proceeds to describe the five races - Bushmanoid, Caucasoid, Mongoloid, Negroid, and Pygmoid - that people the continent of Africa. Thus, we see continuous slippage between populations, tribes, and races, which would plague the theory, methods, and practices of population genetics.

To avoid the methodological errors of previous researchers, Murdock deployed rigorous inclusion criteria for his Ethnographic atlas. Societies were distinguished based on language, ethnic identity, and geographical location. To ensure greater statistical power, samples were randomly selected. Murdock categorized north and northeastern parts of the African continent separately from subSaharan Africa, a practice that would survive in the analyses of contemporary population geneticists. (If included, the neat picture of geographically defined races might disappear.) To find the real Africa, it would be necessary to look below the Sahara. Once ordered in the Atlas in the mid-1960s, societies of the world remain fixed in time, to be utilized by future researchers from other disciplines, including geneticists.

Murdock's treatise influenced future genetic researchers in Africa, especially, for the purposes of our discussion, Cavalli-Sforza. The hunter-gatherer groups described in Murdock's Africa: Its peoples and their culture history were featured on the first page of the introduction to CavalliSforza's (1986) African Pygmies, a detailed compilation of virtually all the studies conducted to date on population structure, genetics, anthropometry, and other biological characteristics of African 'pygmies' (1986). Importantly, Murdock's classification of Central African pygmies framed the conceptualization of pygmies as distinct groups and guided sampling decisions. Cavalli-Sforza (2000) returns again and again to Murdock, most recently in his popular work Genes, peoples, and languages published in 2000. Murdock's Africa appears as one of only three references in the draft document of the sub-Saharan Working Group of the HGDP. While noting that "neither in the present or past is there any simple correlation between ethnicity, language, and gene pool," the sub-Saharan Working Group nonetheless selected groups based on ethnicity and language, using Murdock's maps to determine which populations to include on the final list (Sub-Saharan Africa Working Group, n.d.). The point here is that once ordered into databases, societies of the world remain fixed in time, serving as handy reference guides for future researchers from other disciplines, including geneticists who are unaware of the complex issues raised by the very construction of such a database in the first place.

\section{Conclusion}

The current taxonomy of African languages thus does not reflect primordial ethnicities or point to racial groupings, despite the myths created by both Africans and Westerners. Rather, knowledge of what we now think of as African languages was produced in the nineteenth and twentieth centuries when European and American missionaries, working closely with or against colonial administrators and African intellectuals, initiated their efforts to reduce a rich diversity of spoken dialects to unified written forms. Language then was mobilized to support or undermine ethnic and race consciousness, depending on the social and political environments in different regions of Africa.

During the so-called "Golden Age of Ethnography," university-trained social anthropologists took to the field to systematically study, organize, and order the world's diverse peoples. Intent on creating a scientific methodology of neutral observation, they replaced amateur travelers, traders, colonial administrators, and missionaries as authoritative knowledge producers about the customs, beliefs, and languages of indigenous peoples. At the same time, linguists were engaged in an intensive project of construction and standardization of African languages, mapping language onto primordial "tribal" territories and cultural units. Colonial knowledge systems were built on dynamic, local pre-colonial and colonial social formations 
whose identities changed over time (Spear, 2003). Yet, when incorporated into databases, it was European rules of categorization that governed the organization of this knowledge. Ordering projects, be they political, anthropological, linguistic, or biological in nature, erase the reality that people have always been interacting, exchanging goods, social ideas, culture, and genes (Goodman, 2007). While these exchanges took a particularly brutal form in the colonial interventions that profoundly and irreversibly shaped the constitution of groups in Africa, colonialism did not initiate the movement and mixing of peoples.

Given the history of the production of written languages, ethnic consciousness, and tribalism in Africa, one is left wondering on what historical evidence rests Cavalli-Sforza and Feldman's claim that "most populations are relatively isolated... although rare exchange of marriage partners between groups does occur...Sometimes a whole population (or a fraction of it) migrates and settles elsewhere" (Cavalli-Sforza \& Feldman, 2003, p. 267). To the contrary, historical evidence shows that populations are not now and never were isolated, bounded entities; they are actively produced and lived social formations appearing, disappearing, and re-appearing over time as part of local and global socio-political and scientific projects. Languages such as Tsonga, Manganika, or Zulu are best understood as reflecting identities assigned to and adopted by diverse groups of peoples in specific historical contexts. Constructing these identities produced purity out of mixture, something of great importance to Europeans. It is certainly the case that ethnic identities have acquired profound social meaning. It does not follow, however, that these identities conform to cohesive biological units.

The particularity of African "tribes" described in this essay exists in profound tension with Africa as a flattened geographic space through which the West has constructed a world of lack and deficiency (Ferguson, 2006). The simultaneity of these two visions is captured almost weekly in colorful images of death and destruction on the front page of the New York Times. However, whether trapped in a discourse of sameness or difference, "research on Africa," as Achille Mbembe (2001, p. 17) so eloquently states, “...has underestimated the fact that one characteristic of African societies over the longue duree has been that they follow a great variety of temporal trajectories and a wide range of swings only reducible to an analysis in terms of convergent or divergent evolution at the cost of an extraordinary impoverishment of reality."

\section{Acknowledgments}

We thank Jenny Reardon for providing us with the draft report of the Sub-Saharan Working Group. We also thank John Trimbur for comments on the history of language studies in South Africa and two anonymous reviewers for their helpful comments.

\section{References}

Anonymous, Professor Monica Wilson. (1973, September 13). Woman's Argus (p. 3). University of Cape Town Manuscript and Archives Collection, BUZV Staff, Monica Wilson.
Asad, T. (Ed.). (1973). Anthropology and the colonial encounter. New York: Humanities Press.

Bolnick, D. (2008) Individual ancestry inference and the reification of race as a biological phenomenon. In B. Koenig, S. S.-J. Lee, \& S. Richardson (Eds.), Revisiting race in a genomic age. New Brunswick: Rutgers University Press.

Burchard, E., Ziv, E., Coyle, N., Gomez, S. L., Tang, H., Karter, A. J., et al. (2003). The importance of race and ethnic background in biomedical research and clinical practice. New England Journal of Medicine, 348, 1170-1175.

Cann, H. M., de Toma, C., Cazes, L., Legrand, M.-F., Morel, V., Piouffre, L., et al. (2002). A human diversity cell line panel. Science, 296, 261-262, Supplementary material, Available from. http://www.sciencemag.org/ cgi/content/full/296/5566/261b/DC1.

Cavalli-Sforza, L. L. (Ed.). (1986). African pygmies. Orlando: Academic Press.

Cavalli-Sforza, L. L. (2000). Genes, peoples, and languages. Berkeley: University of California Press.

Cavalli-Sforza, L. L., \& Feldman, M. C. (2003). The application of molecular genetic approaches to the study of human evolution. Nature Genetics, 33(Suppl.), 266-275.

Cavalli-Sforza, L. L., Wilson, A. C., Cantor, C. R., Cook-Deegan, R. M., \& King, M.-C. (1991). Call for a worldwide survey of human genetic diversity: a vanishing opportunity for the human genome project. Genomics, 11, 490-491.

Cohn, B. S. (2004). African models and Indian histories. In An anthropologist among the historians and other essays. New Delhi: Oxford India Paperbacks.

Colson, E. (1951). The plateau of Tonga of northern Rhodesia. In E. Colson, \& M. Gluckman (Eds.), Seven tribes of British central Africa. London: Oxford University Press. On behalf of The Rhodes Livingstone Institute of Northern Rhodesia.

Comaroff, J. L. (1982). Dialectical systems, history and anthropology: units of study and questions of theory. Journal of Southern African Studies, 8(2), 143-172.

Coombes, A. (1995). Reinventing Africa: Museums, material culture and popular imagination in late Victorian and Edwardian England. New Haven: Yale University Press.

Doke, C. M. (1933). A preliminary investigation into the state of the native languages of South Africa with suggestions as to research and the development of literature. Bantu Studies, 7(1), 1-46.

Dubow, S. (1995). Scientific racism in modern South Africa. Cambridge: Cambridge University Press.

Duster, T. (2005). Race and reification in science. Science, 307, 1050-1051.

Duster, T. (2006, February 3). Deep roots and tangled branches. Chronicle of Higher Education.

Evans-Pritchard, E. E. (1950). Kinship and the local community among the Nuer. In A. R. Radcliffe-Brown, \& D. Forde (Eds.), African systems of kinship and marriage (pp. 360-391). London: Oxford University Press.

Ferguson, J. (2006). Global shadows: Africa in the neoliberal world order. Durham: Duke University Press.

Ferraro, G. (1992). Cultural anthropology: An applied perspective. St. Paul: West Publishing Company.

Fortes, M. (1953). The structure of unilineal descent groups. American Anthropologist, 55, 17-41.

Foucault, M. (1976). In M. Bertani, \& A. Fontana (Eds.), Society must be defended: Lectures at the College de France 1975-1976 (pp. 238-263). New York: Picador, 2003.

Gannett, L. (2001). Racism and human genome diversity research: the ethical limits of 'population thinking.'. Philosophy of Science, 68, S479S492.

Gluckman, M. (1940). Analysis of a social situation in modern Zululand. Bantu Studies, 14, 1-30.

Godfrey, \& Wilson, M. (1945). The analysis of social change based on observations in Central Africa. Cambridge: Cambridge University Press.

Goodenough, W. H. (1994). George Peter Murdock: May 11, 1897-March 29, 1985. Biographical Memoirs, 64. Available from. http://www.nap. edu/openbook/0309049784/html/305.html.

Goodman, A. (2007). Toward genetics in an era of anthropology. American Ethnologist, 34(2), 225-227.

Goody, J. (1995). The expansive moment: Anthropology in Britain and Africa, 1918-1970. Cambridge: Cambridge University Press.

Gordon, R. (1990). Early social anthropology in South Africa. African Studies, 49(1), 15-48.

Hailey, L. (1938). An African survey: A study of problems arising in Africa south of the Sahara. London: Oxford University Press.

Hammond-Tooke, W. D. (1997). Imperfect interpreters: South Africa's anthropologists 1920-1990. Johannesburg: Witwatersrand University Press. 
Harries, P. (1981). The anthropologist as historian and liberal: H.-A. Junod and the Thonga. Journal of Southern African Studies, 8, 37-50.

Harries, P. (1987, 9-14 February). The roots of ethnicity: discourse and the politics of language construction in south-east Africa. The making of class. University of Witwatersrand Workshop.

Harries, P. (1989). Exclusion, classification and internal colonialism: the emergence of ethnicity among the Tsonga-speakers of South Africa. In L. Vail (Ed.), The creation of tribalism in Southern Africa (pp. 82-117). London: James Currey Ltd.

Harris, M. (1968). The rise of anthropological theory: A history of theories of culture. New York: Crowell.

International HapMap Consortium. (2003). The international HapMap project. Nature, 426, 789-796.

Junod, H. A. (1927). The life of a South African tribe. London: Macmillan and Co. Ltd.

Kahn, J. (2007). Race-ing patents/patenting race: an emerging political geography of intellectual property in biotechnology. Iowa Law Review, 92, 353-416.

Kittles, R. A., \& Weiss, K. M. (2003). Race, ancestry, and genes: implications for defining disease risk. Annual Review of Genomics and Human Genetics, 4, 33-67.

Kuklick, H. (1991). The savage within: The social history of British anthropology 1885-1945. Cambridge: Cambridge University Press.

Kuper, A. (1996). Anthropology and anthropologists: The modern British school. London: Routledge.

Lestrade, G. P. The Bavenda, circa 1930. Lestrade Papers. University of Cape Town Archives and Manuscripts Collection, BC255, A9.37.

McPherson, R., Pertsemilidis, A., Kavaslar, N., Stewart, A., Roberts, R. Cox, D. R., et al. (2007). A common allele on chromosome 9 associated with coronary heart disease. Science, 316, 1488-1491.

Magubane, B. (1971). A critical look at the indices used in the study of social change in colonial Africa. Current Anthropology, 12, 419-445.

Makoni, S. (1998). African languages as European scripts: the shaping of communal memory. In S. Nuttal, \& C. Coetzee (Eds.), Negotiating the past: The making of memory in South Africa (pp. 242-248). Cape Town: Oxford University Press.

Malinowski, B. (1929). Practical anthropology. Africa, 2(1), 22-38.

Malinowski, B. (1930). Kinship. Man, 30, 19-29.

Malinowski, B. (1935). Letter to Godfrey Wilson. January 20. University of Cape Town Archives and Manuscript Collection, Monica and Godfrey Wilson Papers, BC 880, B4.5 Malinowski.

Mbembe, A. (2001). On the postcolony. Berkeley: University of California Press.

M'Charek, A. (2005). The human genome diversity project: An ethnography of scientific practice. Cambridge: Cambridge University Press.

Michler, B. L. (2003). Biographical study of H.-A. Junod: The fictional dimension. M.A. dissertation, University of Pretoria.

Moffat, R. (1844). Missionary labours and scenes in southern Africa. New York: Robert Carter.

Moore, S. F. (1993). Changing perspectives on a changing Africa: the work of anthropology. In R. B. Bates, V. Y. Mudimbe, \& J. O’Barr (Eds.), African and the disciplines: The contributions of research in Africa to the social sciences and humanities (pp. 3-57). Chicago: University of Chicago Press.

Mountain, J. L., \& Risch, N. (2004). Assessing genetic contributions to phenotypic differences among 'racial' and 'ethnic' groups. Nature Genetics, 36, S48-S53.
Mudimbe, V. Y. (1988). The invention of Africa: Gnosis, philosophy, and the order of knowledge. Bloomington and Indianapolis: Indiana University Press.

Murdock, G. P. (1957). World ethnographic sample. American Anthropologist, 59, 664-687.

Murdock, G. P. (1958). Outline of world cultures. New Haven: Human Relations Area Files Press.

Murdock, G. P. (1959). Africa: Its peoples and their culture history. New York: McGraw-Hill Book Company, Inc.

Murdock, G. P. (1967). Ethnographic atlas. Pittsburgh: University of Pittsburgh Press.

Radcliffe-Brown, A. R. (1925). Letter to Winifred Hoernle, August 20. University of Cape Town Manuscripts and Archives Collection, Isaac Schapera Papers, BC 1168, D.

Radcliffe-Brown, A. R. (1935). On the concept of function in social science. American Anthropologist, New Series, 37(3 Part I), 394-402.

Radcliffe-Brown, A. R. (1946). A note on functional anthropology. Man, 46, 38-41.

Ranger, T. (1989). Missionaries, migrants and the Manyika: the invention of ethnicity in Zimbabwe. In L. Vail (Ed.), The creation of tribalism in Southern Africa (pp. 118-150). London: James Currey Ltd.

Reardon, J. (2005). Race to the finish: Identity and governance in an age genomics. Princeton: Princeton University Press.

Report of the Inter-Departmental Board on Zulu Orthography. (1926) Lestrade Papers. University of Cape Town, Manuscript and Archives Collection, BC255, A1.2

Rosenberg, N. A., Pritchard, J. K., Weber, J. L., Cann, H. M., Kidd, K. K., Zhivotovsky, L. A., et al. (2002). Genetic structure of populations. Science, 298, 2381-2385, Supporting online material, Available from. www.sciencemag.og/cgi/content/full/298/5602/2381/DC1.

Schapera, I. (1970). Tribal innovators: Tswana chiefs and social change, 1795-1940. New York: Humanities Press.

Schumaker, L. (2001). Africanizing anthropology: Fieldwork, networks, and the making of cultural knowledge in Central Africa. Durham and London: Duke University Press.

Spear, T. (2003). Neo-traditionalism and the limits of invention in British Colonial Africa. Journal of African History, 44, 3-27.

Stocking, G., Jr. (1984). Radcliffe-Brown and British social anthropology. In G. Stocking (Ed.), Functionalism historicized: Essays on British social anthropology (pp. 131-191). Madison: University of Wisconsin Press.

Sub-Saharan Africa Working Group. (n.d.). Human Genome Diversity Project draft document.

Tishkoff, S. A., \& Williams, S. M. (2002). Genetic analysis of African populations: human evolution and complex disease. Nature Reviews Genetics, 3, 611-621.

Vail, L. (1989). Introduction: ethnicity in southern African history. In L. Vail (Ed.), The creation of tribalism in Southern Africa (pp. 1-20). London: James Currey Ltd.

Wade, N. (2002, December 20). Gene study identifies 5 main human populations, linking them to geography. New York Times 37.

Wade, N. (2005, October 27). Genetic catalog may aid search for roots of disease. New York Times 20.

Wilson, M. (1935). Letter to Winifred Hoernle, May 9th. University of Cape Town Manuscripts and Archives, Wilson Papers, BC880, D11 Correspondence with IIALC.

Wilson, M., \& Thompson, L. (Eds.). (1969-1971). The Oxford history of South Africa II: South Africa 1870-1966. New York: Oxford University Press. 